\title{
Penerapan Maqashid Asy-Syari'Ah Pada Sistem Ekonomi Syariah
}

\author{
Ujang Ruhyat Syamsoni \\ Institut Agama Islam Yasni Bungo \\ Email: ruhyatujang2016@gmail.com \\ M. Syukri Ismail \\ Institut Agama Islam Yasni Bungo \\ Email: msyukriismail@iaiyasnibungo.ac.id
}

\begin{abstract}
Maqāshid asy-syari'ah is the most decisive factor in giving the products of sharia economy that can play a role (socio-control tool and socio-economy development) to produce the benefit of human, but also more than that, Maqāshid asy-syari'ah can provide a rational philosophical dimension toward Islamic economic laws which are appeared in contemporary Islamic economic ijtihad activities. Maqāshid asy-syari'ah will provide a rational and substantial pattern of thought in a view at shariah agreements and shariah banking products. It is only with Maqāshid asy-syari'ah that shariah banking and financial products can develop and respond to rapidly changing business progress. Without Maqāshid ash-shari'ah, then all understanding of syari'ah economy, finance, and syari'ah banking will be narrow and rigid. The value of Maqāshid ash-shari'ah will produce the flexible jurisprudence, agile and always able to conform with the times (shalihun fi kulli zamān wa makān). This research uses the qualitative method, through literature study approach using available data. The application of Maqāshid asy-syari'ah will make Islamic Financial Institution grow faster and create new products creatively, so that as not inferior to conventional bank products.
\end{abstract}

Keywords:Maqashid Syariah, Sharia Economy, Maslahah.

\begin{abstract}
Abstrak
Maqāshid asy-syari'ah merupakan merupakan faktor yang paling menentukan dalam melahirkan produk-produk ekonomi syari'ah yang dapat berperan ganda (alat sosial-kontrol dan rekayasa socio-economy) untuk mewujudkan kemaslahatan manusia, tetapi juga lebih dari itu, Maqāshid asy-syari'ah dapat memberikan dimensi filosofis rasional terhadap produk-produk hokum ekonomi Islam yang dilahirkan dalam aktifitas ijtihad ekonomi syari'ah kontemporer. Maqāshid asy-syari'ah akan memberikan pola pemikiran yang rasional dan substansial dalam memandang akad-akad dan produk-produk perbankan syari'ah. Hanya dengan Maqāshid asy-syari'ah-lah produk perbankan dan keuangan syari'ah dapat berkembang dengan baik dan dapat merespon kemajuan bisnis yang terus berubah dengan cepat. Tanpa Maqāshid asy-syari'ah, maka semua pemahaman mengenai ekonomi syari'ah, keuangan, dan perbankan syari'ah akan sempit dan kaku. Jiwa Maqāshid asy-syari'ah akan mewujudkan fikih mu'amalah yang elastis, flesibel, lincah dan senantiasa bisa sesuai dengan perkembangan zaman (shalihun fi kullī zamān wa makān). Penerapan Maqāshid asy-syari'ah akan membuat bank syari'ah dan LKS semakin cepat berkembang dan kreatif menciptakan produk-produk baru, sehingga tidak kalah dengan produk-produk bank konvensional.
\end{abstract}

Kata kunci: Maqāshid asy-syari'ah, Ekonomi Syariah, Maslahah. 
Ujang Ruhyat, M. Syukri Ismail :Penerapan Maqashid Asy-Syari'Ah...

\section{A. Pendahuluan}

Perkembangan ekonomi dan bisnis syari'ah dewasa ini terlihat semakin pesat khususnya di Indonesia. Hal ini terbukti dengan berdirinya beberapa Lembaga Keuangan Syari'ah, seperti perbankan syari'ah, asuransi syari'ah, pasar modal syari'ah, reksadana syari'ah, baitul māl wa at-tamwīl, koperasi syari'ah, pegadaian syari'ah dan lain-lain. Ekonomi dan bisnis syari'ah ini tidak hanya dalam bentuk lembaga-lembaga bank maupun non-bank, akan tetapi juga meliputi aspek-aspek perekonomian yang lebih luas, seperti ekonomi makro dan mikro dan masalah-masalah ekonomi lainnya.

Secara ekonomis, perbankan syari'ah dikembangkan sebagai solusi atas ketidakmampuan sistem ekonomi ribawi selama ini dalam menghadapi permasalahan ekonomi yang semakin banyak dan kompleks. Lebih dari itu, tujuan utama dari sistem perbankan syari'ah adalah untuk mencapai dan mewujudkan kesejahteraan umat secara luas dunia dan akhirat. Dengan mengacu pada tujuan utama ini, maka maqāshid asy-syari'ah menjadi sandaran utama dalam setiap pengembangan operasional dan produk-produk yang ada di bank syariah.

Para ulama ushul fikih sepakat bahwa pengetahuan maqāshid asy-syari'ah menjadi syarat utama dalam berijtihad untuk menjawab berbagai problematika kehidupan ekonomi dan keuangan yang terus berkembang. Maqāshid asy-syari'ah tidak saja diperlukan untuk merumuskan kebijakan-kebijakan ekonomi makro (moneter, fiskal, public finance), tetapi juga untuk menciptakan produk-produk perbankan dan keuangan syariah serta teori-teori ekonomi mikro lainnya. Selain itu maqāshid asy-syari'ah juga sangat diperlukan dalam membuat regulasi perbankan dan lembaga keuangan syari'ah.

Maqāshid asy-syariah tidak saja menjadi faktor yang paling menentukan dalam melahirkan produk-produk ekonomi syari'ah yang dapat berperan ganda sebagai alat sosial kontrol dan rekayasa socio-economy untuk mewujudkan kemaslahatan manusia, tetapi lebih dari itu, maqāshid asy-syari'ah dapat memberikan dimensi filosofis dan rasional terhadap produk-produk hukum ekonomi syariah yang dilahirkan dalam aktivitas ijtihad ekonomi syari'ah kontemporer.Maqāshid asy-syari'ahakan memberikan pola pemikiran yang rasional dan substansial dalam memandang akad-akad dan produk-produk perbankan syariah. Sedangkan pemikiran fikih semata akan menimbulkan pola pemikiran yang formalistik dan tekstualis. Hanya dengan pendekatan maqāshid asy-syari'ah-lah produk perbankan dan keuangan syariah dapat berkembang dengan baik dan dapat merespon kemajuan bisnis yang terus berubah dengan cepat.

\section{B. Definisi dan Dasar Penetapan Maqāshid Asy-Syari'ah}

Maqāshid asy-syari'ah (مقاصدالشريعة) terdiri dari dua kata yaitu maqāshid dan asy-syari'ah yang hubungan antara satu dan lainnya dalam bentuk idhāfah (mudhāf dan mudhāfun ilaihi) (Azhari: 2011: 293). Kata Maqāshid adalah adalah jamak dari kata maqshad (مقدر) yang artinya adalah maksud dan tujuan. ${ }^{1 K a t a}$ asy-syari'ah (الشريعة) yang sejatinya berarti hukum Allah swt yang berhubungan dengan tingkah laku manusia yang bersifat amaliyah (praktis). ${ }^{2}$ baik yang ditetapkan sendiri oleh Allah SWT berdasarkan al-Qur'an, maupun ditetapkan Nabi SAW sebagai penjelasan atas hukum yang ditetapkan Allah SWT, atau dihasilkan oleh mujtahid. berdasarkan apa yang ditetapkan oleh Allah swt. atau dijelaskan oleh Nabi SAW Definsi lain dari syariah adalah segala hukum dan aturan yang ditetapkan Allah swt. bagi hamba-Nya untuk diikuti, yang mengatur hubungan antara manusia dengan Allah swt., hubungan antara manusia dengan manusia, dan hubungan antara manusia dengan lingkungan dan kehidupannya. ${ }^{3}$

${ }^{1}$ Ahmad WarsonMunawwir. Kamus Arab-Indonesia Terlengkap.(Surabaya: Pustaka Progressif, 1997). h. 1124

${ }^{2}$ Amir Syarifuddin.Ushul Fiqh. (Jakarta: Prenada, 2009) cet. IV, Jilid. 2. h. 2

${ }^{3}$ FahurrahmanDjamil. Hukum Ekonomi Islam: Sejarah, Teori dan Konsep.(Jakarta: Sinar Grafika, 2013). h. 31 
Berdasarkan arti dari kedua kata tersebut, maka istilah maqāshid asy-syari'ah memiliki makna sebagai apa yang dimaksud oleh Allah swt. dalam menetapkan hukum, apa yang dituju oleh Allah swt. dalam menetapkan hukum atau apa yang ingin dicapai oleh Allah swt. dalam menetapkan suatu hukum. ${ }^{4}$ Pendapat lain mendefinisikan maqāshid asy-syari'ah sebagai maksud atau tujuan disyariatkan hukum Islam. ${ }^{5}$

Menurut asy-Syatibi, maqāshid asy-syari'ah dapat dipilah menjadi dua bagian, yaitu maqshûd asy-syari' dan maqshûd mukallaf. Lebih lanjut, as-Syatibi menjelaskan bahwa maqshûd asy-syari' terdiri dari empat bagian, yaitu: pertama, Qashdu asy-Syari' fi wadh'i asy-Syari'ah (tujuan Allah swt dalam menetapkan Syari'at); kedua, Qashdu asy-Syari' fi wadh'i asy-Syarā'ah lil ifhām (tujuan Allah swt dalam menetapkan syari'ahnya ini adalah agar dapat dipahami); ketiga, Qashdu asy-Syari' fi wadh'i asy-Syarīah li al-Taklïf bi muqtadhaha (tujuan Allah swt dalam menetapkan syari'ah agar dapat dilaksanakan); keempat, Qashdu asy-syari'fi dukhûl al-Mukallaf Tahta Ahkām asy-Syarī'ah (Tujuan Allah swt mengapa individu harus menjalankan syari'ah). ${ }^{6}$

Dalam kajian ilmu Ushul Fiqh, maqāshid asy-syarīah mengandung arti yang sama dengan kata al-hikmah (1), yang memiliki makna tujuan yang dimaksud Allah swt. dalam penetapan suatu hukum.7Dengan kesamaan arti ini maka Ibnu 'Āshûr mendefinisikan maqāshid asy-syarīah 'sebagai makna-makna lebih mendalam dan aspek-aspek baik dari kebijaksanaan (hikam), yang dipertimbangkan oleh pembuat hukum (Allah swt.) menyangkut semua atau sebagian besar bidang dan keadaan dalam pembuatan hukum. ${ }^{8}$ Sedangkan Riyādh Manshûr alKhalïfĩ dalam tulisannya mendefinisikan maqāshid asy-syarī‘ah sebagai makna-makna dan hikmah-hikmah yang diinginkan pembuat syariat (Allah swt.) dalam penetapan hukum untuk kemaslahatan makhluk-Nya di dunia dan akhirat. ${ }^{9}$ Dalam tulisan ini penulis cenderung mendefinisikan maqāshid asy-syarī'ah sebagai maksud serta hikmah yang ingin dicapai oleh Allah swt. dalam menetapkan suatu hukum atau aturan demi tercapainya kemaslahatan bagi seluruh makhluk-Nya, baik di dunia maupun akhirat.

Ada empat cara menurut Ibn 'Asyur untuk dapat mengetahui maqāshid asy-syarīah. Pertama, melalui istiqra' (penalaran Induktif) terhadap ayat-ayat al-Qur'an yang secara eksplisit mengungkapkan nilai-nilai, sama ada yang merupakan tujuan sekunder dari ayat-ayat ibadah ataupun nilai-nilai yang bersifat duniawi dari ayat-ayat mu'amalah. Melalui penelitian ini dijumpai bahwa syari'at agama Islam membawa kemaslahatan bagi manusia di dunia dan di akhirat.Kedua, melalui pengetahuan 'illat perintah dan larangan. Cara ini lebih menekankan maslak al-illah, yaitu cara yang digunakan untuk mencari sebab-sebab disyari'atkannya suatu hokum dalam penalaran qiyasi. Ketiga, melalui perintah dan larangan yang jelas.Keempat, melalui ungkapan (ta'bir) yang menunjukkan tujuan syari'at. ${ }^{10}$

\section{Maŝlahah sebagai Dasar Maqūôîid asy-Syarī'ah}

Maŝlahah secara etimologi berarti sesuatu yang baik, dirasakan lezat, oleh karenanya menimbulkan kesenangan dan kepuasan serta diterima oleh akal yang sehat.Amir Syarifuddin dalam bukunya Ushul Fiqh menjelaskan bahwa tujuan Allah swt. dalam menetapkan hukum adalah untuk memberikan kemaslahatan kepada umat manusia dalam kehidupannya di dunia, maupun dalam persiapannya menghadapi kehidupan akherat. Oleh karena itu, beliau menyatakan bahwa maqūsisid asy-syarīah adalah maslahah itu sendiri. ${ }^{11}$ Izzudin ibn Abdi al-Salam

${ }^{4}$ Amir, Ushul Fiqh, Ibid. h. 231.

${ }^{5}$ Fathurrahman. Hukum ekonomi Islam, Ibid. h. 5.

${ }^{6}$ MuhammadMufid. Ushul Fiqh Ekonomi dan Keuangan Kontemporer : dari Teori ke Aplikasi,(Jakarta: Kencana Prenada Media Group, 2016). h. 171.

${ }^{7}$ Yûsuf Ahmad Muhammadal-Badwi.Maqāshid asy-syarī'ah 'inda Ibn Taimiyah.(al-Urdun: Dār anNafā'is, t.t). h. 55 .

8ISRA.Sistem Keuangan Islam: Prinsip dan Operasi. (Jakarta: Rajawali Pers, 2015). h. 200.

${ }^{9}$ Riyādh Manshûr. al- al-Khalīfi. Maqāshid asy-Syarī'ahwa Atsaruhā fì Fiqhi al-Mu'āmalat alMāliyah.Majallah Jāmi'ah al-Malik 'Abdul 'Azīz: al-Iqtishād al-Islāmī, Vol. 17, No. 1, Tahun, 2004. h. 8

${ }^{10}$ MuhammadMufid. Ushul Fiqh Ekonomi dan Keuangan Kontemporer. Ibid. h. 177-182

${ }^{11}$ Amir, Ushul Fiqh, Ibid. h. 232. 
جلبالمصالح menyatakan bahwa pada dasarnya maslahat itu mencakup dua prinsip utama, yakni (mewujudkan kebaikan) dan در \& المفاسد (menolak/mencegah kerusakan).12

Dari segi tujuan yang hendak dicapai, maslahah dibagi dalam dua kelompok, yaitu:

1. Mendatangkan manfaat kepada umat manusia, baik bermanfaat untuk hidup di dunia maupun akherat.

2. Menghindarkan kemudaratan (bahaya) dalam kehidupan manusia, baik kemudaratan di dunia maupun akhirat. (Amir Syarifuddin: 2009: 233).

Dari segi apa yang menjadi sasaran atau ruang lingkup yang dipelihara dalam penetapan hukum, maka maslahah dibagi menjadi lima, yaitu:

1. Memelihara agama atau keagamaan (حفظالدين)

2. Memelihara jiwa atau diri atau kehidupan (حفظالنفس)

3. Memelihara akal (حفظلعقل)

4. Memelihara keturunan (حفظالنسل)

5. Memelihara harta (Jنظال)

Kelima hal di atas disebut oleh al-Ghazali sebagai limamaqāshid asy-syarīah. Dari segi tingkat kepentingan memeliharanya, maslahah yang menjadi bagian dari maqāshid asy-syarī‘ah terbagi kepada tiga tingkatan, yaitu:

1. Tingkat primer (الضروريات) yaitu sesuatu yang sangat perlu dipelihara atau diperhatikan, seandainya tidak atau terabaikan akan membawa kepada tidak ada atau tidak berartinya kehidupan.

2. Tingkat sekunder (الحاجيات) yaitu suatu kebutuhan untuk memeliharanya, namun bila tidak dipelihara tidak membawa pada hancurnya kehidupan, tetapi hanya menimbulkan kesulitan atau kekurangan dalam melaksanakannya.

3. Tingkat tertier (التحسينيات) yaitu sesuatu yang sebaiknya dilakukan untuk mengambil manfaat dan sebaiknya ditinggalkan untuk menghindari kemudaratan. ${ }^{14}$ Muhammad Ayub dalam bukunya Understanding Islamic Finance, memaparkan bahwa secara keseluruhan tujuan di balik syariat Allah swt. adalah kebahagian dan kesejahteraan manusia di dunia dan akherat, dan semua hal yang menjamin kesejahteraan dan memenuhi kepeningan utama dari umat manusia tercakup dalam tujuan-tujuan syariah (maqāshid asy-syarīah).15Tujuan-tujuan tersebut dapat dibagi dalam dua kelompok, yaitu:

1. Tujuan Primer

Tujuan primer yang ingin diwujudkan oleh syariah adalah perlindungan dan pemeliharaan atas:
a) Agama.
b) Kehidupan.
c) Keturunan - anggota keluarga.
d) Harta.
e) Intelek.

2. Kehormatan. ${ }^{16}$ Tujuan Sekunder

Tujuan primer syariah akan membawa ke beberapa tujuan sekunder yang terdiri atas:

a) Penegakan keadilan dan kesamaan dalam masyarakat.

b) Peningkatan keamanan sosial, sikap saling membantu, dan solidaritas, khususnya untuk membantu yang miskin serta membutuhkan dalam memenuhi kebutuhan dasar mereka.

12Izzudin ibn Abdi al-Salam.Qawāid al-Ahkām fi mashalih al-anām, Terj. Kaidah-Kaidah Hukum Islam, (Bandung: Nusa Media, 2011). h. 3.

${ }^{13}$ Amir, Ushul Fiqh, Ibid. h. 232-238.

${ }^{14}$ Ibid. h. 239-240.

${ }^{15}$ MuhammadAyub. Understanding Islamic Finance: A-Z Keuangan Syariah.(Jakarta: Gramedia Pustaka Utama, 2009). h. 34.

16Ibid. h. 35 
Ujang Ruhyat, M. Syukri Ismail :Penerapan Maqashid Asy-Syari'Ah...

c) Pemeliharaan kedamaian dan keamanan.

d) Peningkatan kerjasama dalam hal kebaikan dan larangan perbuatan serta tindakan jahat.

e) Peningkatan nilai moral universal yang utama dan semua tindakan yang perlu untuk pemeliharaan dan penguasaan alam. ${ }^{17}$

\section{Pembangunan Ekonomi Berbasis Maqāshid asy-Syarīah}

Masuknya teori maqāshid asy-syarīah ke dalam wilayah ekonomi Islam dapat ditemukan langsung dalam landasan etika.Para pelaku ekonomi tidak hanya dituntut untuk dapat menguasai sumber-sumber ekonomi yang strategis tetapi juga memanfaatkannya untuk kepentingan umat dengan mengacu pada kemaslahatan primer, sekunder, maupun tertier. Dengan demikian, bagi kajian ekonomi Islam, maqāshid asy-syarīah adalah salah satu usaha logis yang wajib diterapkan sebagai konsekuensi dari pemahaman ekonomi yang berkeadilan di satu sisi dan berketuhanan di sisi lain.

Indikator-indikator pembangunan ekonomi yang didasarkan pada maqāshid syarīah menurut 'Abdul Mun'im Afar sebagaimana dikutip oleh Ali Rama dan Makhlani dapat dilihat dari: 18

1. PemeliharaanAgama

Jika pokok-pokok ibadah seperti mengucapkan kalimat syahadat, pelaksanaan sholat, zakat, haji dan lain-lain, adalah sebagai indicator bagi terpeliharanya keberadaan agama, maka segala sesuatu yang mutlak dibutuhkan baik materil maupun non materil, sarana barang dan jasa-untuk melaksanakan ibadah tersebut harus tersedia dan terealisasi terlebih dahulu. Kebutuhan dasar tersebut antara lain merujuk pada identifikasi kebutuhan berupa sarana, barang dan jasa sebagaiberikut:

a. Untuk menjaga kesinambungan iman dan akidah maka setidaknya perlu disediakan antara lain: jasa da'i dan pembimbing ibadah, pencetakan dan penerbitan buku-buku agama termasuk Alquran dan Hadis, pendirian pusat-pusat pengajian dan bimbingan agama.

b. Untuk melaksanakan ibadah yang terdiri dari:

1) Shalat, dibutuhkan masjid dan musholla, jasa imam dan muadzin, dana-dana waqaf untuk biaya pemeliharaan tempat ibadah, dan penyediaan fasilitas-fasilitas penunjang lainnya.

2) Zakat, dibutu h kan pembentukan struktur kelembagaan zakat yang terintegrasi dan dikelola secara profesional dantransparan, pelatihan manajemen pengumpulan, pengelolaan dan distribusi zakat, pemetaan potensi pengumpulan dana zakat dari para muzakki dan pemetaan sebaran mustahiq zakat, penegakan hokum bagi pihak yang tidak mau membayar zakat, pembentukan lembaga yang intens mensosialisasikan kewajiban membayar zakat serta hukum-hukum agamanya.

3) Puasa, dibutuhkan lembaga pendidikan yang mengajarkan hukum-hukum puasa, penciptaan lingkungan yang mendukung lancarnya pelaksanaan puasa, menyemarakkan kegiataan keagamaan selama bulan Ramadhan.

4) Haji, diperlukan pembentukan lembaga pengelolaan pelaksanaan haji dan lembaga pengelola dana haji, penyediaan alat transportasi dan penginapan yang nyaman dan lembaga bimbingan haji dan pengajaran manasik haji.

5) Lembaga peradilan, dibutuhkan jasa kepemimpinan kepala negara, majelis permusyawaratan, para hakim, lembaga urusan Islam.

6) Lembaga keamanan: jasa aparat keamanan untuk menjaga keselamatan para pelaksana dakwah, keamanan masyarakat dan negara dan memberikan hukuman bagi para pelanggar aturan-aturan yang berlaku.

2. Pemeliharaan Jiwa dan Akal

17Ibid. h. 36

${ }^{18}$ Ali dan MakhlaniRama."Pembangunan Ekonomi dalam Tinjauanmaqāshid asy-syarīah”.Dialog: Jurnal Penelitian dan Kajian Keagamaan.Vol. 1, No. 1, Juni 2013. h. 31-46 
Kebutuhan akanpemeliharaan jiwa dan akal meliputi makan dan minum, berpakaian dan bertempat tinggal (kebutuhan akan rumah). Artinya kebutuhan akan pangan, sandang dan papan adalah mutlak harus terpenuhi untuk menjaga jiwa dan akal manusia, agar dapat menjaga eksistensi hidup serta menjalankan fungsi utamanya sebagai pelaku utama pembangunan (khalifah). Terpenuhinya kebutuhan dasar tersebut adalah merupakan hak dasar dari setiap individu.Pembangunan ekonomi harus menempatkan pemenuhan kebutuhan dasar setiap individu sebagai prioritas utama, karena jika tidak terpenuhi akanmengancam eksistensi hidup manusia (jiwa). Pemeliharaan keselamatan jiwa meliputi Sembilan bidang pokok:

a. Makanan pokok dan perlengkapan penyajiannya, lauk-pauk beserta bumbu- bumbu, air bersih dan garam.

b. Perangkat perlengkapan untuk pemeliharaan badan.

c. Pakaian.

d. Perumahan

e. Pemeliharaan kesehatan dengan ketersediaan rumah sakit, peralatan sakit, obat-obat, dokter, ambulans, dan lain-lain.

f. Transportasi dan telekomunikasi berupa alatt ransportasi darat, laut dan udara dan alatalat komunikasi.

g. Jasa keamanan bagi individu dan masyarakat.

h. Lapangan yang halal dan manusiawi, upah yang adil, dan kondisi kerja yang nyaman.

i. Lembaga perlindungan sosial seperi pemeliharaan lanjutusia, anak yatim piatu,bantuan bagi para penganggur dan jaminan sosial.

Sedangkan pemeliharaan akal dapat terdirii dari:

a. Pendidikan: penyediaan lembaga pendidikan dari tingkat dasar sampai perguruantinggi, biaya pendidikan yang rendah bahkan gratis, penyediaan alokasi dana yang tinggi untuk sektor pendidikan, penyediaan sarana pendidikan yang memadai termasuk guru dan tenaga pengajar.

b. Penerangan dan kebudayaan.

c. Penelitian ilmiah: pusat pengembangan kurikulum, pusat pengembangan ilmu modern, pusatpenelitian, dan lain-lain.

3. PemeliharaanKeturunan dan Harta

Tidak ada peradaban yang mampu bertahan jika generasi mudanya memiliki kualitas spiritual, fisik dan mental yang rendah, sehingga berdampak pada ketidakmampuan untuk menghadapii tantangan kehidupan yang semakin dinamis.Oleh karenanya mesti dilakukan perbaikan secara terencana dan berkelanjutan untuk memperbaikii kualitas generasi muda.Salah satu langkah untuk memperbaiki karakter dan keperibadian mereka adalah dengan menanamkan akhlak baik (khuluq hasan) melalui prosestarbiyah (pendidikan) di lingkungan keluarga dan lembaga pendidikan.

Sementaraharta merupakan fasilitas yang dianugerahkan Allahswt.Kepada manusia untuk menunjang fungsi utamanya sebagai khalîfah di bumi.Harta adalah amanah yang harus dikembangkan secara terencana untuk tujuan menghilangkan kemiskinan, memenuhi kebutuhan dasar setiap individu, membuat kehidupan terasa nnyaman dan mendorong terciptanya distribusi pendapatan dan kekayaan yang merata.Dalam memperoleh dan mengembangkan harta dituntut untuk didasarkan pada nilai-nilai Islam.Harus ada filter moral dalam pengelolaannya.

Untuk menjaga keselamatan keturunan dan harta maka dibutuhkan lembagalembaga yang terkaitdengan:

a. Pemeliharaan keturunan

1) Lembaga pernikahan yang akanmempermudah legalitas pernikahan, pembelakan pra-pernikahan, pembinaan rumah tangga pasca pernikahan, dan lain-lain.

2) Pusat pembinaan ibu-ibu berkenaan dengan kesehatan, psikologi, dan makanan, pemeriksaan rutin untuk memastikan kesehatan dan keselamatan janin.

3) Pemeliharaan anak-anak: bimbingan dan pendidikan kesehatan bagi anak-anak, lembaga pengasuhan anak, program dasar untuk kesehatan dan nutrisi anak, 
Ujang Ruhyat, M. Syukri Ismail :Penerapan Maqashid Asy-Syari'Ah...

penanaman akidah yang benar dan prinsip-prinsip dasar agama Islam, memberikan bekal keahlian bagi anak-anak kurang mampu.

4) Yayasan anak yatim sebagai pusat pemeliharaan anak-anak yatim.

5) Pembentukan lembaga pemeliharaan harta.

6) Pembentukan lembaga keuangan dan investasi.

7) Strategi keuangan akurat untuk pembangunan dan pemeliharaan harta.

8) Pengamanan pemeliharaan harta dengan penerapan hukuman atas pencuri, perampas harta dan pelaku kecurangan, pelarangan riba, suap dan korupsi.

9) Menjamin keamanan harta dan kepemilikan pribadi, pengaturan aka-akad transaksi seperti jual beli, perkongsian, sewa,danlain-lain.

10) Pengajaran berkenaan dengan tatacara mendapatkan harta dan pengembangannya, sumber-sumber pendapatan halal dan haram, hukum-hukum transaksi, dan lain- lain.

Berdasarkan uraian di atas, maka konsep kebutuhan dasar yang harus menjadi prioritas pembangunan ekonomi adalah segala kebutuhan dasar minimal yang harus ada dan diperlukan untuk menjaga keselamatan agama, jiwa, kekuatan jasmani, akal dan harta manusia, agar setiap individu dapat melaksanakan kewajiban terhadap diri sendiri, keluarga, masyarakat, sistem sosial dan keamanan; kebutuhan yang dimaksud mencakup segala macam barang dan jasa primer, sebagai sarana yang harus dihasilkan dalam proses pembangunan dengan perencanaan yang tepat disertai anggaran yang memadai.

Oleh karenanya, pembangunan berbasis maqāshid asy-syarīah adalah pembangunan yang meletakkan prioritas utamanya untuk memenuhii kebutuhan dasar manusia demi terpeliharanya lima maslahat pokok (agama, akal, jiwa, keturunan dan harta) melalui usaha dalam proses produksi atau pembangunan ekonomi.Terpenuhinya kebutuhan dasar setiap individu akan berkorelasi pada peningkatan kesejahteraan atau tercipta kesejahteraan. Sebaliknya, apabila manusiatidak mampu memenuhi kebutuhan dasarnya, ia akan merasakan ketidakpuasan, tidak damai, tidak senang, tidak bahagia, tidak aman. Kondisi ini adalah kondisi tidak sejahtera.

Dengan demikian terdapat hubungan antara pembangunan ekonomi yang berbasis maqāshid asy-syarī'ah dengan pemenuhan kebutuhan dasar hidup manusia, dan juga hubungannya dengan kondisi kesejahteraan, yang bila disimpulkan bahwa pembangunan ekonomi yang memprioritaskan pemenuhan kebutuhan dasar manusia adalah merupakan predisposisi dari kesejahteraan, dalam arti kesejahteraan sosial akan ditentukan oleh bagaimana masyarakat dapat memenuhi kebutuhan dasar.

\section{E. Aplikasi Maqāshid Asy-Syarī'ah dalam Ekonomi Syariah}

Berbicara ekonomi dan transaksi keuangan syari'ah sangat erat kaitannya dengan prinsip Maqāshid Asy-Syarīah, yaitu hifz al-mal (menjaga harta benda).Dengan demikian, transaksi muamalat memiliki landasan epistimologinya yang bersumber pada penalaran maqāshid asy-syarī'ah.Tujuan syari'at dalam transaksi mu'amalat adalah menciptakan kesejahteraan umat manusia dengan menyeimbangkan peredaran harta benda antara kaum kaya dan kaum miskin secara berkeadilan dan seimbang.

Menurut thahir ibn 'Asyur-sebagaimana dikutip al-Raisuni bahwa maqāshid asy-syarī'ah dalam ekonomi syari'ah dapat dibagi menjadi lima tujuan, yaitu: rawaj (diperjualbelikan), wudhuh (kejelasan), hifz (penjagaan), tsabat (ketetapan) dan 'adl (keadilan). Yang dimaksud dengan rawaj berarti bahwa harta benda ditujukan untuk diperjualbelikan agar kekayaan tersebut menjadi berkembang.Wudhuh berarti harta ditujukan agar dikelola secara transparan dan akuntabel.Hifz berarti harta sebagai barang titipan Allah swt ditujukan agar dipelihara dan dibelanjakan secara syar'i.Tsabat berarti harta benda ditujukan untuk membangkitkan etos kerja yang tinggi dalam mengelolanya dan mengembangkannya dengan cara-cara yang sah dan halal.'Adl berarti harta harus dikelola secara berkeadilan tanpa menzalimi orang lain.

Konsep Maqāshid Asy-Syarīah dalam ekonomi syari'ah menduduki posisi yang sangat penting dalam merumuskan ekonomi syari'ah, menciptakan produk-produk perbankan dan keuangan syari'ah. Berikut beberapa implikasi Maqāshid Asy-Syarīåh dalam sistem ekonomiIslam. 
Ujang Ruhyat, M. Syukri Ismail :Penerapan Maqashid Asy-Syari'Ah...

\section{Maqāshid Asy-Syarīah dalam Proses Produksi}

Islam tidak menolak pertimbangan bahwa untuk memproduksi barang atau jasa harus mempertimbangkan for whom to produce sehingga akan menentukan what to produce. Dengan mengacu pada konsep maslahah sebagai tujuan dari maqāshid asy-syarī‘ah, maka proses produksi akan terkait dengan beberapa faktor berikut: pertama, karena produsen dalam Islam tidak hanya mengejar profitability namun juga menjadikan maslahah sebagai barometernya, maka ia tidak akan memproduksi barang atau jasa yang tidak searah dengan maqāshid asysyarīah dan menyalahi al-kulliyah al-khamsah. Kedua, dalam banyak hal, jenis dan jumlah supply relatif pada demand. Jika diasumsikan bahwa semua demand di suatu pasar berdasar pada maslahah yang berakar pada needs. Maka supply dari produsen akan mengikuti demand tersebut. Meskipun demikian, masih ada demand yang tidak sesuai dengan kemaslahatan, maka produsen dalam ekonomi Islam semestinya tidak menyuplai permintaan tersebut hanya karena profit semata. ${ }^{19}$

\section{Maqāshid Asy-Syarī'ah dalam Konsumsi}

Dalam ekonomi konvensional, konsumen diasumsikan mempunyai tujuan untuk memperoleh kepuasan (utility) dalam kegiatan konsumsinya.Utility secara bahasa berarti berguna (usefulness), membantu (helpfulness) atau menguntungkan (advantage).Dalam konteks ekonomi, utilitas dimaknai sebagai kegunaan atau kepuasan yang dirasakan oleh seseorang konsumen dalam mengonsumsi suatu barang. Namun terkadang seseorang menginginkan suatu kepuasan yang tinggi terhadap suatu barang dan jasa, akan tetapi justru barang atau jasa tersebut membawa kerusakan kepada dirinya atau orang-orang disekitarnya.

Dalam Islam, tujuan konsumsi bukanlah konsep utilitas melainkan kemaslahatan (maslahah). Pencapaian maslahah tersebut merupakan tujuan dari maqāshid asy-syarīah itu sendiri. Konsep utilitas sangat subjektif karena bertolak belakang pada pemenuhan kepuasan atau wants, konsep maslahat relative lebih objektif karena bertolak pada pemenuhan kebutuhan atau needs. Maslahat dipenuhi berdasarkan pertimbangan rasional normatif dan positif, maka ada kriteria objektif tentang suatu barang ekonomi yang memiliki nilai maslahat atau tidak. ${ }^{20}$

\section{Maqāshid Asy-Syarīah dalam Kebijakan Fiskal}

Kebijakan fiskal didefinisikan sebagai kebijakan pemerintah yang berkaitan dengan penggunaan pajak, pinjaman masyarakat, pengeluaran masyarakat oleh pemerintah untuk tujuan stabilitas atau pembangunan, sehingga terbentuk modal dan laju pertumbuhan ekonomi yang berjalan dengan baik.Dasar kebijakan fiskal secara umum bertujuan untuk pemerataan pendapatan dan kesejahteraan.Akan tetapi kesejahteraan dalam Islam mencakup kesejahteraan dunia akhirat (falah), oleh karena itu nilai-nilai moral harus mendasari kebijakan fiskal.

Kesejahteraan yang dimaksud dalam kebijakan fiskal Islam yaitu kebijakan pemerintah dalam pengembangan masyarakat yang didasari atas distribusi kekayaan berimbang dengan menempatkan nilai-nilai material dan spiritual dalam tingkat yang seimbang.Kebijakan fiskal dalam Islam, regulasi pemasukan dan pengeluaran merupakan salah satu dari berbagai perangkat untuk mencapai kemaslahatan.Kemaslahatan adalah segala bentuk keadaan, baik material maupun immaterial, yang mampu meningkatkan kedudukan manusia sebagai makhluk yang paling sempurna.

Maqāshid asy-syarī’ah sebagai dasar kebijakan fiskal memiliki peranan yang sangat urgen dalam pembangunan ekonomi.Kebijakan fiskal dalam Islam tidak bertumpu pada mekanisme pasar bebas yang membolehkan mengejar kepentingan setiap individu tanpa campur tangan pemerintah sehingga telah melahirkan individualisme ekonomi. Prinsip kebijakan fiskal dalam Islam bertujuan untuk mengembangkan suatu masyarkat yang didasarkan atas distribusi kekayaan berimbang dengan menempatkan kepentingan material dan spiritual pada tingkat yang sama.

\footnotetext{
${ }^{19}$ MuhammadMufid. Ushul Fiqh Ekonomi dan Keuangan Kontemporer. Ibid. h. 188-189.

20Ibid. h. 189-190.
} 
Instrumen kebijakan fiskal dalam ekonomi Islam dapat dikategorikam dalam tiga hal, yaitu masalah penerimaan Negara, pengeluaran Negara, dan utang Negara.Namun yang paling menonjol dalam kebijakan fiskal adalah masalah pajak.Dalam konteks ekonomi Islam, system pajak ini termasuk dalam penerapan kewajiban membayar zakat, jizyah, fa'i, ghanimah, dan lain-lain.

Dalam sistem dan kebijakan fiskal Islam, zakat memiliki kedudukan istimewa dan strategis karena sebagai sumber pendapatan yang utama.Zakat dapat menunjang pengeluaran Negara, baik dalam bentuk governmentexpenditure, government transfer, sehingga mampu meningkatkan kesejahtreaan rakyat. Zakat dapat dianggap sebagai system fiskal komprehensif yang memiliki kelengkapan aturan mencakup subjek, objek, tarif, nisab, haul, hingga lokasi distribusinya.

Dengan demikian, maqāshid asy-syarī‘ah dalam konteks kebijakan fiskal islam adalah adanya keadilan dalam pemerataan pendapatan dalam rangka mencapai kesejahteraan masyarakat. Disinilah pemerintah dituntut dalam kebijakan ekonomi yang menyangkut hajat masyarakat publik bersifat adil dan berimbang. ${ }^{21}$

\section{F. Penutup}

Konsep ekonomi Islam adalah suatu keniscayaan yang harus dikembangkan lebih jauh, tidak hanya dalam tataran konseptual teapi juga dalam tataran praktis, khususnya praktek di perbankan syariah.Islam telah menyediakan sumber-sumber tekstual yang memadai untuk memberikan batasan prilaku manusia, namun hal itu tidak cukup jika tidak diimbangi dengan inferensi sosial. Adanya teori maqāshid asy-syarīah dalam kajian perekonomian Islam merupakan langkah maju dalam pengembangan model ekonomi Islam yang paling ideal. Hal ini karena maqāshid asy-syarī'ah dapat dijadikan alat bantu dalam membantu menyelesaikan dalil dalam menetapkan suatu hukum dalam rangka mencapai tujuan disyariatkannya hukum tersebut.

\section{Daftar Pustaka}

al-Azharī, Mushthafā Mahmûd. Taisīr Qawā'id an-Nahwi lil Mubtadi'īn. Mesir: Maktabah al-'Ulûm wa al-Hikam, 2011.

al-Badwi, Yûsuf Ahmad Muhammad. Maqāshid asy-syarīah 'inda Ibn Taimiyah.al-Urdun: Dār anNafā'is, t.t.

al-Khalīfi, Riyādh Manshûr. al- Maqāshid asy-Syarī'ahwa Atsaruhā fì Fiqhi al-Mu'āmalat alMāliyah.Majallah Jāmi'ah al-Malik 'Abdul 'Azīz: al-Iqtishād al-Islāmī, Vol. 17, No. 1, Tahun, 2004.

Arifin, Jaenal.Kamus Ushul Fiqh Dalam Dua Bingkai Ijtihad. Jakarta: Kencana, 2012

Asy-Syātibī Abû Ishāq Ibrāhīm ibn Mûsā ibn Muhammad al-Lakhmī.al-Muwāfaqāt. al-Mamlakah as-Su'ûdiyyah al-'Arabiyyah: Dār 'Affān, cet. 2, 1997.

Ayub, Muhammad. Understanding Islamic Finance: A-Z Keuangan Syariah. Jakarta: Gramedia Pustaka Utama, 2009.

Bābistī, 'Azīzah Fawal. Al-Mu'jam al-Mufashshil fi an-Nahwi al-'Arabī. Beirut: Dār al-Kutub al 'Ilmiyyah, 1992.

Djamil, Fahurrahman. Hukum Ekonomi Islam: Sejarah, Teori dan Konsep. Jakarta: Sinar Grafika, 2013.

${ }^{21}$ Ibid. h. 190-192. 
Ujang Ruhyat, M. Syukri Ismail :Penerapan Maqashid Asy-Syari'Ah...

Fathurrahman, Ayif. "Pendekatan Maqāshid Asy-Syarī'Ah: Konstruksi Terhadap Pengembangan Ilmu Ekonomi dan Keuangan Islam”.Hunafa: Jurnal Studia Islamika, Vol. 11, No. 2, Desember 2014.

ISRA.Sistem Keuangan Islam: Prinsip dan Operasi. Jakarta: Rajawali Pers, 2015.

Izzudin ibn Abdi al-Salam.Qawāid al-Ahkām fi mashalih al-anām, Terj. Kaidah-Kaidah Hukum Islam, Bandung: Nusa Media, 2011.

Lahsasna, Ahcene. Maqāshid asy-Syarīa ah in Islamic Finance.Kuala Lumpur: IFBIM, 2013.

Mufid, Muhammad. Ushul Fiqh Ekonomi dan Keuangan Kontemporer : dari Teori ke Aplikasi, Jakarta: Kencana Prenada Media Group, 2016.

Munawwir, Ahmad Warson. Kamus Arab-Indonesia Terlengkap.Surabaya: Pustaka Progressif, 1997.

Rama, Ali dan Makhlani.“Pembangunan Ekonomi dalam Tinjauanmaqāshid asy-syarī'ah”.Dialog: Jurnal Penelitian dan Kajian Keagamaan.Vol. 1, No. 1, Juni 2013.

Syarifuddin, Amir.Ushul Fiqh. Jakarta: Prenada, cet. IV, Jilid. 2, 2009. 